\title{
THE ROLE OF EDUCATIONAL WORK IN EDUCATIONAL INSTITUTIONS IN ORDER TO PREVENT THE INFLUENCE OF HARMFUL FACTORS ON THE HUMAN BODY
}

\author{
Alla Shlianina, Iryna Shelyuk, Svitlana Mulenko, Elena Shemet
}

The growing number of allergic diseases among people is a global problem. The article considers the role of educational work among students as an important component of knowledge formation about the causes of allergic diseases, prevention methods and maintaining a healthy lifestyle. It is established, that this problem is relevant in the world and requires the introduction of a system of measures to overcome it. The prevalence of allergic diseases has tripled in the last 10 years and to date allergies have reached pandemic proportions. The stages of allergic reactions and possible causes of allergic diseases (genetic, environmental, social) are indicated. The result of immunodeficiency as a result of allergies is the development of various complications or chronic diseases that can lead to disability and even death. The complex epidemiological situation in the world with a large increase in the number of allergic diseases requires constant monitoring to understand current trends. It is taken into account, that there are no statistical data on the level of prevalence of allergic diseases among the population of Ukraine, the study of epidemiological and preventive areas is relevant.

The problem of allergic manifestations was considered among the applicants for education of Zhytomyr Pharmaceutical Basic Vocational College. It has been found, that students of the college already have certain professional competencies: demonstrate knowledge and understanding of the concept of "allergy", the manifestation of allergies, treat the causes and ways of the disease, methods of diagnosing allergens, are informed about historical aspects of disease recognition. It has been proven, that issues, related to allergies, worry students because of the causes of their allergic reactions and diseases. It has been found, that students want to continue to receive and deepen modern knowledge on prevention, causes and types of allergic manifestations and ways to eliminate them. As a result of the analysis the actual questions of students and the necessary answer to them, teachers and specialists-allergists have been revealed.

The importance of information work among applicants for pharmaceutical education, which in their daily work will constantly use toxic substances, drugs and cosmetics that contain substances - allergens, has been traced.

Substantiation of the need to develop effective systems of actions for prevention, diagnosis and provision of treatment and prevention care to the population has been presented

Keywords: toxic substances, cosmetics, ingredients, allergy, allergic reaction, allergens, allergen skin tests, prevention

\section{How to cite:}

Shlianina, A., Shelyuk, I., Mulenko, S., Shemet, E. (2021). The role of sanitary and educational work in educational institutions in order to prevent the influence of harmful factors on the human body. ScienceRise: Pedagogical Education, 6 (45), 35-39. doi: http://doi.org/10.15587/25194984.2021.249006

(C) The Author(s) 2021

This is an open access article under the Creative Commons CC BY license hydrate

\section{Introduction}

The annual increase in the number of people with allergic diseases is a global problem of our time and causes great medical, social and economic losses. According to the World Allergy Organization, about $40 \%$ of the world's population has one or more allergic diseases [1]. Allergopathology today is a group of chronic diseases, the prevalence of which is recently ahead of cardiovascular and cancer. In this regard, there is a growing need to prevent, detect and control these diseases in the early stages and throughout life.

Given the urgency of the problem, the article focuses on the interaction of medical, pharmaceutical, chemical and educational professionals in the context of the formation of professional and life skills in young people to prevent the impact of harmful factors on the human body.

\section{Literary review}

The analysis of scientific works [2, 3] shows that issues, related to the high prevalence of allergic diseases, are one of the main tasks of public health around the world, as well as the subject of research in various regional and international epidemiological, immunological and clinical studies. Allergic reactions, according to various authors, are registered in more than $60 \%$ of the world's population, of which more than $30 \%$ are children. Not all sensitized patients have clinically pronounced symptoms, their severity varies from mild to hard, the manifestations may be intermittent and persistent [4]. 
The rapid increase in the prevalence of these diseases in recent years is due to the increase in xenobiotics in human life, environmental pollution, consumption of instant food, and also indicates that the driving force in this process is also environmental factors. Increased industrialization and urbanization have led to an increase in organic and inorganic pollutants $[5,6]$.

Predisposition to food allergies is also associated with anatomical, physiological and immunological disorders of the digestive system, which can lead to pathology of digestion and absorption of food. Genetically determined predisposition to allergies is important in the formation of food sensitization. Additional risk factors are excessive protein nutrition, use of preservatives, dyes in the food and cosmetics industry, the presence of harmful components that manufacturers use to extend the shelf life and improve the consumer properties of their products [5-8].

Allergic diseases are also affected by stress. Urticaria is an example of an acute allergic reaction under stress. Stress does not always cause allergic reactions, but in the presence of a trigger, it can aggravate allergic reactions or cause symptoms. At the same time, allergic diseases can cause stress. Therefore, there is a certain dependence of allergies on stress. Normalization of emotional state reduces the frequency of allergies and the condition of a person with allergies [3].

The pathogenesis of chronic spontaneous urticaria is not yet fully understood due to imperfect stages of diagnosis and treatment, which requires greater use of the latest arsenal of immunobiological agents based on monoclonal antibodies in allergists' clinical practice [9].

In developed countries, the number of cases of drug allergies has increased. About $40 \%$ of hospital patients suffer from pathological reactions, associated with drug allergies. The ratio of detected and undetected patients in Ukraine with drug allergies is 1: 1000 [3]. Proper diagnosis of drug hypersensitivity reactions is very important for both the patient and the health care system. However, the diagnosis of an allergic reaction to drugs is complex, time-consuming, not standardized for many drugs, includes procedures that are not risk-free, and in most cases there are no standardized in vivo and in vitro tests.

There are many new effective methods of examination and treatment, one of which is ASIT therapy, the essence of which is to introduce into the human body microdoses of allergens, to which it responds and, consequently, the development of intolerance to allergens. This technique is equivalent to allergy vaccination. Tests are also used to detect allergens by blood tests - determination of total immunoglobulin $\mathrm{E}$ and specific immunoglobulin E. Today in Ukraine, diagnostics using ALEX tests has become quite accessible, which allows to detect allergens in children from six months of age.

\section{Research aim and tasks}

The purpose of the article is to draw attention to the need for educational work in educational institutions with the involvement of allergists for early prevention of the disease, prevention of harmful factors on the human body and the possibility of allergen-specific immunotherapy.
To achieve this goal, the following tasks were set:

1. To determine the level of awareness of students of the College of Pharmacy on the causes, diagnosis, treatment and prevention of allergic diseases.

2. To determine the level of manifestation of allergic reactions of students of the College of Pharmacy.

3. Development, planning of methods and measures, aimed at preventing and overcoming the manifestation of allergic reactions.

\section{Materials and methods}

The study was conducted on the basis of Zhytomyr Basic Pharmaceutical Vocational College. The sample consisted of students of various specialties of III years, numbering 114 people. The study used the developed author's questionnaire, focused on studying the impact of harmful factors on the human body. The study was conducted with groups of college students during October 2021. The subjects gave their informed consent to participate in a research, focused on studying the effects of harmful factors on the human body.

\section{Research results}

There are no accurate statistics on allergic diseases in Ukraine, only approximate calculations can be used. According to them, there are about $7 \%$ of patients with hay fever in Ukraine, $8 \%$ with perennial rhinitis, and $5 \%$ with bronchial asthma [3]. Thus, about 9 million people in Ukraine suffer from allergic diseases. Early symptoms of the disease often remain undetected, so the actual number of patients is greater.

In order to study the relevance of the problem of allergic reactions, we conducted a sample survey among 114 respondents - students of education in the first and second year of Zhytomyr Basic Pharmaceutical Vocational College of Zhytomyr Regional Council. The survey covered various questions, aimed at establishing students' awareness of what allergies are, the causes of allergic manifestations and ways to eliminate them, the disclosure of their own problems of allergic reactions.

The mechanism of biochemical allergic reactions is considered by students during the study of the discipline "Biological Chemistry". In order to ensure deep and complete mastery of the chosen specialty, the formation of skills of independent research and creative approach to solving current scientific, practical and theoretical problems, students are engaged in scientific, teaching and research activities, involved in the Student Scientific Society of the college, considering the question of the impact of harmful factors on the human body.

Thus, during the round table, dedicated to the World Allergy Day, students presented the results of their research work, which revealed historical information about the first mention of allergies from the chronicles of ancient Egyptian papyri, from the descriptions of skin rashes and digestive disorders after eating certain foods, given by Hippocrates and Lucretius, from the works of a famous Roman physician Galen, Persian scientist and physician Avicenna, and others.

Stages of allergic reactions, in which certain changes and disorders occur, were also considered. At the first (immunological) stage the first contact of the organism with an allergen begins, as a result of which 
sensitized lymphocytes (antibodies) are formed. During this period, the body's sensitivity increases, as a result of which the body is able to react violently to the repeated introduction of an antigen. The first injection of an allergen is called sensitizing; repeated, which directly causes the manifestations of allergies - final. As a result, the body becomes hypersensitive or sensitized to a specific allergen. When a specific allergen is re-introduced into the body, antigen-antibody (Ag-At) or Ag-sensitized lymphocyte complexes are formed.

In the next stage of biochemical reactions, the formed antibodies combine with the re-introduced allergen, which disrupts metabolic processes in cells that contain antibodies on their surface; cells are destroyed, and allergy mediators are released - histamine, serotonin and other mediators of inflammation, resulting in increased capillary permeability, inflammatory edema.

At the last pathophysiological stage, functional and structural disorders occur, which is a corresponding reaction of cells, organs and tissues of the body to the mediators, formed in the previous stage. A dysfunction of the body with inherent allergic reactions is clinically manifested $[3,10]$.

\subsection{Analysis of the obtained data and their sta- tistical processing}

The study found that most educators are aware of various issues, related to allergic diseases. They know the types and signs of allergies; causes and circumstances that contribute to the occurrence of allergic diseases; understand the mechanism of laboratory methods for detecting allergens using allergy tests, screening tests and own observations by trial and exception, etc.

Among the respondents, $76.3 \%$ had (have) manifestations of allergic reactions (Fig. 1), which lasted (last) over: week $(26.3 \%)$, day $(22.8 \%)$, month $(9.6 \%)$, constantly (8.8\%), different time interval (32.5\%) (Fig. 2).

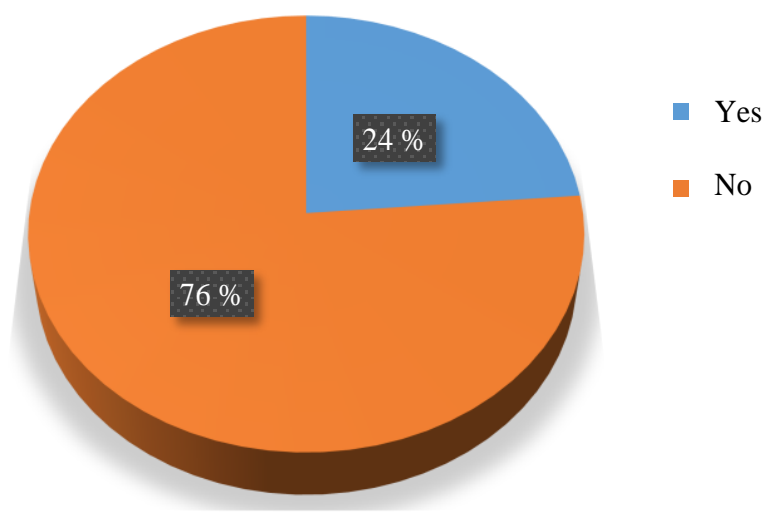

Fig. 1. Presence of allergic reactions manifestations

Allergens that cause allergic reactions in students have been identified: detergents and cosmetics, dust, medicines, vaccines, plants, plant pollen, insect bites, sun, cold, food, animal hair, polluted air and more.

To the question "Have you observed manifestations of allergic reactions during laboratory classes in chemical disciplines?" $12.2 \%$ of respondents gave a positive answer. The duration of such manifestations in students was short and not severe. Such data focus teachers' attention on the methods and techniques of performing chemical experiments by students, avoiding harmful factors.

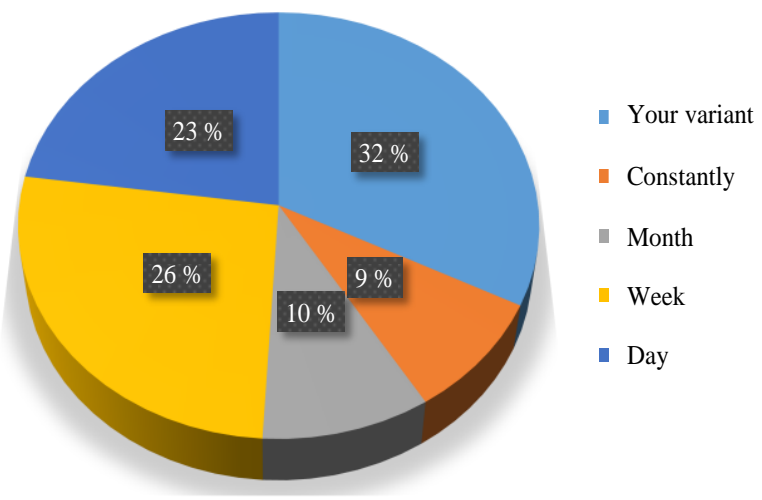

Fig. 2. Duration of allergic reactions manifestations

To the question "What factors contributed (contribute) to manifestations of your allergic reactions?" Applicants gave the following answers: environment $(50.9 \%)$, lifestyle $(12.3 \%)$, heredity $(7 \%) .29 .8 \%$ of respondents did not indicate the factors that cause allergies, as $23.7 \%$ of them did not notice its manifestations (Fig. 3).

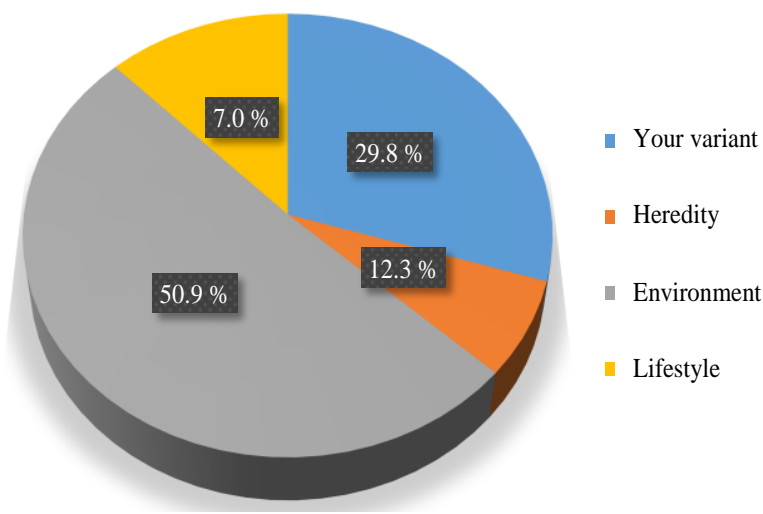

Fig. 3. Factors, causing allergic reactions manifestations

Training practices under the guidance of a teacher of chemical disciplines must be accompanied by students' undergoing primary (secondary, targeted, etc.) training in occupational safety. Students have competencies in the rules of use and storage of chemical reagents, are familiar with the list of toxic, potent, volatile reagents that can cause allergic reactions. Applicants use personal protective equipment when working with toxic and aggressive substances. Chemical experiments that may contaminate training laboratories with toxic substances (chlorine, bromine, hydrogen sulfide, carbon monoxide, benzene, chloroform, formalin, ammonia, etc.) must be performed in a fume hood. It is not allowed to perform experiments, analyzes with the release of vapors and gases of highly toxic chemicals.

During laboratory classes in the discipline "Cosmetic Chemistry" students analyze the composition of cosmetics according to the chemical nature of their ingredients, identify organic and inorganic components, using physical, chemical and physico-chemical (instru- 
mental) methods of analysis. Particular attention is paid to substances that cause allergic reactions. Among the most common allergens among cosmetics, analyzed by students, are: aniline synthetic dyes, vaseline, lanolin, hydroquinone, hydrogen peroxide, propylene glycol, salicylic and benzoic acids, iron compounds. Most students are interested in this discipline, trying to master the competencies of determining the composition of cosmetics to avoid the impact of dangerous factors on the body and find safe alternatives.

To eliminate manifestations of allergies, $63.2 \%$ of respondents used (use) drugs, $9.6 \%$ of respondents were not treated (are not treated) at all; $7 \%$ of respondents changed their lifestyle. $20.2 \%$ of the surveyed students did not indicate their version of the answer to measures to eliminate allergic manifestations, because they did not have such manifestations in their lives (Fig. 4).

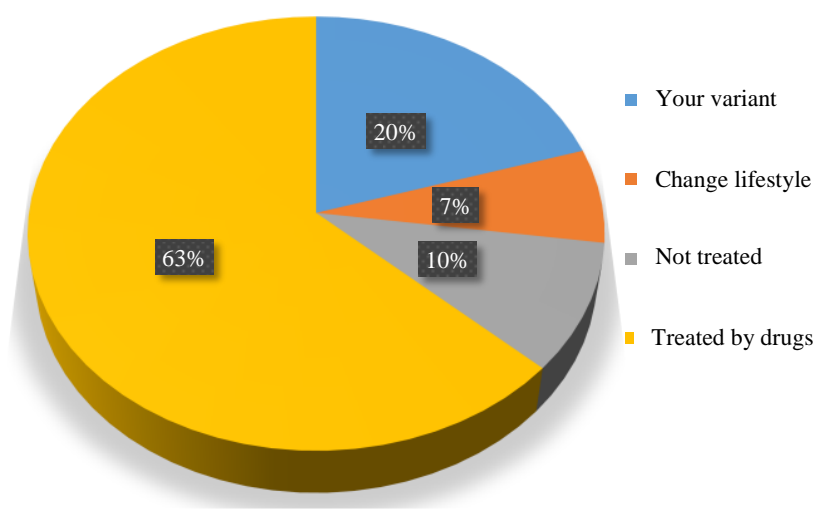

Fig. 4. Measures for eliminating allergic manifestations

Questionnaires among educators showed their desire to increase their competence in allergen-specific immunotherapy. In the proposed form of the questionnaire, students had the opportunity to write their questions, the answers to which they want to get from teachers and allergists:

- Is it possible to get rid of allergies forever? symptoms?

- Are allergy manifestations possible without lergens?

- What modern world methods help to identify al-

- How to distinguish allergies from other diseases?

- At what age are hereditary allergic reactions?

- What are the myths about allergies?

- What is the mechanism of different types of allergic reactions?

- How to get rid of allergies to bright light (constant sneezing)? forever?

- What effective methods can get rid of allergies

- How much can the immunity of a person who has allergies and does not take antihistamines for treatment weaken? shock?

- Can allergies occur due to severe nervous

- Do allergies get worse with age? Ukraine?

- What species of allergens can be analyzed in

- Why are the effects of drugs on allergies different?
- Why do allergic manifestations disappear over time without treatment and lifestyle changes?

Students receive answers to these and other questions during the study of specialized disciplines, as well as during extracurricular activities.

Modern science of allergology provides answers to various questions. This has been made possible by scientific advances, the improvement of diagnostic systems, the modernization of medical equipment and the development of next-generation drugs in recent decades in our country and abroad. Modern laboratory tests play an important role in the diagnosis of allergic diseases, identification of the type of allergic reactions, which facilitates the correct diagnosis, and, as a consequence, the appointment of the necessary treatment.

Given the peculiarities of the working conditions of pharmacists, future professionals should be informed about the possible manifestations of allergic reactions due to contact with allergens - components of drugs and cosmetics. It is advisable to use a certain algorithm for pharmaceutical care for allergies:

- identify allergy symptoms;

- establish the connection of allergy symptoms with possible contact with the allergen;

- alleviate the symptoms of allergies (avoid contact with potential allergens, take eliminating measures to external allergens, apply a hypoallergenic diet);

- consult a doctor to clarify the diagnosis and conduct therapy [11].

We see prospects for further research in studying the effects of allergens on the human immune system, including those seeking education.

The obtained results of the research testify to the need to keep statistical data on the progression of allergic diseases, to develop an effective strategy and tactics of response, to improve the medical service, to provide timely treatment and prevention care to the population. This will stimulate the scientific and civil society to take active action to prevent the disease.

\section{Conclusions}

In accordance with the tasks we can draw the following conclusions:

1. Most students of the College of Pharmacy are aware of various issues, related to allergic diseases. They know the types and signs of allergies; causes and circumstances that contribute to the occurrence of allergic diseases; understand the mechanism of laboratory methods for detecting allergens using allergy tests, screening tests and own observations by trial and exception, etc.

2. Students of the College of Pharmacy have a high level of allergic reactions ( $75 \%$ of subjects).

3 . The level of awareness of students of the College of Pharmacy about the factors that contribute to the occurrence of allergic reactions is sufficient. Students found that allergens that cause allergic reactions include detergents and cosmetics, dust, medications, vaccines, plants, plant pollen, insect bites, sun, cold, food, animal hair, polluted air, and more.

4. Students of the College of Pharmacy showed an average level of awareness about measures, aimed at eliminating allergic manifestations. The results of the study indicate the need for students of the College of 
Pharmacy to increase their competence in allergenspecific immunotherapy; explanatory work among future specialists in the pharmaceutical field on the possible impact on them of harmful and dangerous factors of drugs and cosmetics, the implementation of measures to prevent disease.
5. Among the measures to prevent allergic reactions, an important place is given to promotion in the family, educational institutions, society as a whole: adherence to healthy lifestyles, stress avoidance, controlled use of medicines and cosmetics, household chemicals, improving environmental competence.

\section{References}

1. World Allergy Organization (WAO) Diagnosis and Rationale for Action against Cow's Milk Allergy (DRACMA) Guidelines (2010). Pediatric Allergy and Immunology, 21. doi: http://doi.org/10.1111/j.1399-3038.2010.01068.x

2. Voronenko, Yu. V., Kuznetsova, L. V., Pukhlyk, B. M. et. al.; Voronenko Yu. V. (Ed.) (2008). Alerholohiia. Kyiv, 366.

3. Okhotnikova, E. N. (2008). «Allergicheskii marsh»: sviaz pokolenii i eskalatsiia allergii u detei. Klinichna imunologiia. Alergologiia. Infektologiia, 4 (15). Available at: https://kiai.com.ua/ru/archive/2008/4\%2815\%29/article-199/-allergicheskiy-marshsvyaz-pokoleniy-i-eskalaciya-allergii-u-detey

4. Bala, A. M., Chursinova, Iu. V. (2019). Ispolzovanie multipleksnykh issledovanii dlia personalizatsii profilia sensibilizatsii i prognoza razvitiia allergicheskikh zabolevanii. Allergologiia i immunologiia, 20 (1), 32-33.

5. Pukhlik, B. M., Viktorov, A. P., Zaikov, S. V. (2008). Lekarstvennaia allergiia i pobochnye effekty lekarstvennykh sredstv v allergologii. Lviv: Meditsina svitu, 107.

6. Kordon, T. I. (2008). Food allergies: etiological factors, problems of diagnosis and role in the formation of diseases of the gastrointestinal tract. Naukovyi visnyk Uzhhorodskoho universytetu. Seriia: Biolohiia, 33, 163-167. Available at: http://nbuv.gov.ua/UJRN/Nvuu_2012_33_26

7. Radchenko, O. M. (2009). Khronichna retsydyvna kropyvianka z pohliadu terapevta: stan problemy (ohliad literatury). Klinichna imunolohiia. Alerholohiia. Infektolohiia, 8 (27), 38-40.

8. Besh, L. V. (2012). Atopichnyi dermatyt u ditei: analiz diahnostychnykh i taktychnykh pomylok. Zdorovia Ukrainy, 3, 34-35.

9. Duda, L. V. (2020). Epidemiolohichna kharakterystyka alerhichnykh zakhvoriuvan u ditei za rezultatamy pohlyblenoho obstezhennia. Young science 2.0. Kyiv, 20-22.

10. Mokronosova, M. A. (2015). Algoritm allergodiagnostiki s pozitsii dokazatelnoi meditsiny. Astma i allergiia, 2, 3-5.

11. Lycc, L. B. (2004). Problemy pischevoi allergii v gastroenterologii. Lechaschii vrach, 4, 68-70.

Alla Shlianina*, Methodist Lecturer, Cycle Commission of Chemical Disciplines, Zhytomyr Applied College of Pharmacy Zhytomyr Oblast Council, Chudnivska str., 99, Zhytomyr, Ukraine, 10005

Iryna Shelyuk, PhD, Cycle Commission of Chemical Disciplines, Zhytomyr Applied College of Pharmacy Zhytomyr Oblast Council, Chudnivska str., 99, Zhytomyr, Ukraine, 10005

Svitlana Mulenko, Lecturer Highest Qualification Category, Cycle Commission of Chemical Disciplines, Zhytomyr Applied College of Pharmacy Zhytomyr Oblast Council, Chudnivska str., 99, Zhytomyr, Ukraine, 10005

Olena Shemet, Lecturer Highest Qualification Category, Cyclic Commission of Medical and Biological Disciplines, Zhytomyr Applied College of Pharmacy Zhytomyr Oblast Council, Chudnivska str., 99, Zhytomyr, Ukraine, 10005

*Corresponding author: Alla Shlianina, e-mail: shlianina.alla@ pharm.zt.ua 